\title{
Combined estrogenic and anti-estrogenic properties of estetrol on breast cancer may provide a safe therapeutic window for the treatment of menopausal symptoms
}

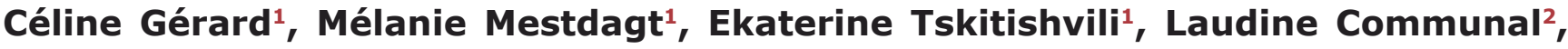 \\ Anne Gompel ${ }^{2,3}$, Elisabete Silva ${ }^{4}$, Jean-François Arnal ${ }^{5}$, Françoise Lenfant ${ }^{5}$, Agnès \\ Noel $^{1}$, Jean-Michel Foidart ${ }^{1}$ and Christel Péqueux ${ }^{1}$ \\ ${ }^{1}$ Laboratory of Tumor and Development Biology, GIGA-Cancer, University of Liège, Liège, Belgium \\ ${ }^{2}$ Gynaecological Endocrinology Unit, Paris Descartes University, Hôpitaux Universitaires, Paris, France \\ 3 INSERM U 938, UPMC, Paris \\ ${ }^{4}$ Institute of Environment, Health and Societies, Brunel University London, UB83PH Uxbridge, United Kingdom \\ ${ }^{5}$ INSERM U1048, Institut des Maladies Métaboliques et Cardiovasculaires, University of Toulouse, UPS, Toulouse, France \\ Correspondence to: Christel Péqueux, email: C.Pequeux@ulg.ac.be \\ Keywords: estetrol, menopause, breast cancer, estrogen receptor, SERM \\ Received: March 03, $2015 \quad$ Accepted: May 02, $2015 \quad$ Published: May 19, 2015
}

This is an open-access article distributed under the terms of the Creative Commons Attribution License, which permits unrestricted use, distribution, and reproduction in any medium, provided the original author and source are credited.

\section{ABSTRACT}

Increased risk of breast cancer is a critical side effect associated with the use of a menopausal hormone therapy (MHT). Estetrol (E4) is a natural estrogen produced by the human fetal liver and is a promising compound for clinical use in MHT. However, its impact on breast cancer is controversial and poorly defined. In this preclinical study, we show that E4 acts as a weak estrogen by stimulating the growth of hormonedependent breast cancer only at concentrations exceeding menopausal therapeutic needs. E4 presents also an antitumor activity by decreasing the strong proliferative effect of estradiol (E2). While estrogen receptor alpha (ERa) is the predominant receptor mediating its effects, the dual weak-estrogenic/anti-estrogenic feature of E4 results from differential signaling pathways activation. Both nuclear and rapid extra-nuclear signaling pathway are necessary for a complete estrogenic effect of E4. However, the antitumor action of E4 is not due to a capacity to antagonize E2-induced nuclear activity. Altogether, our results highlight that E4 has a limited impact on breast cancer and may offer a safe therapeutic window for the treatment of menopausal symptoms.

\section{INTRODUCTION}

Menopausal complaints such as hot flushes, sexual and sleep disorders or loss of bone mineral density are usually relieved by the administration of an estrogen [1]. However, menopausal hormone therapy (MHT) has been associated with severe side effects. Due to their strong hepatic impact, estrogens increase the incidence of thromboembolic events [2-4]. Moreover the administration of an estrogen combined with progestin increases the risk of breast cancer [3, 5-7]. These observations highlight the need to develop new MHT with safer compounds that retain the beneficial effects of estrogens on the bone, uro-genital and central nervous systems, while exhibiting minimal impact on hepatic and mammary tissues.

Estetrol (E4) is a natural estrogen exclusively produced by the human fetal liver during pregnancy [8]. Several animal and in vitro studies indicate that $\mathrm{E} 4$ presents a biological profile similar to selective estrogen receptor modulators (SERMs). It exhibits estrogenlike effects on the brain [9-11], bone [12], uterus [1315], ovulation [16] and atheroma prevention [13]. E4 also presents anti-estrogenic properties in vascular and central nervous systems since it prevents E2 actions on endothelial NO synthase activation, acceleration of endothelial healing and on allopregnanolone synthesis $[10,13]$. In addition, E4 decreases the proliferative effect of E2 on normal breast epithelial cells [17]. E4 has a 
considerably lower impact on coagulation and hemostasis than ethinylestradiol (EE) or estradiol (E2) and might therefore have a minimal impact on the incidence of thromboembolic events (Foidart, Congress of Eur. Soc. Gynecol. 2013, personal communication).

These unique pharmacological properties support that E4 is a suitable and safe compound for MHT. However, the impact of E4 on breast cancer is only partially documented, poorly understood and controversial. It has been reported that E4 prevents and suppresses mammary tumor growth in rats treated with DMBA (7,12dimethylbenz(a)anthracene) as efficiently as ovariectomy or tamoxifen [18]. However, in vitro studies conducted in ER-positive breast cancer cell lines revealed that E4 promotes cell growth [19, 20]. In a clinical study of women with ER-positive breast cancer, it was recently observed that E4 was pro-apoptotic but did not decrease the expression of the proliferation marker Ki-67 in tumor cells [21]. Finally, Giretti [22] reported that E4 moderately stimulates breast cell migration and invasion but is also able to antagonize the effect of E2 on these processes.

Seventy percent of breast tumors express the estrogen receptor alpha $(\mathrm{ER} \alpha)$. In these cancers, E2 acts as a growth factor promoting tumor growth through a highly complex and not fully understood signaling system. Most of the actions of E2 are mediated by nuclear receptors $\mathrm{ER} \alpha$ and $\mathrm{ER} \beta$ [23]. In a classical way, after dimerization and co-regulators recruitment, the E2/ER complexes can directly bind estrogen responsive element (ERE) in the promoter region of target genes to modulate their expression. ER can also act as co-activators for other transcription factors such as AP-1 and Sp1 that mediate the transcription of genes whose promoters do not harbor ERE [24, 25]. Besides these nuclear effects, E2 also elicits extra-nuclear actions related to rapid signaling pathway activation and commonly referred as membrane initiated steroid signaling (MISS) [26-28]. These effects are mediated through a pool of membrane-anchored ER $\alpha$. Another putative estrogen membrane receptor termed $G$ protein-coupled estrogen receptor 1 (GPER), also referred as GPR30, has been proposed to contribute to physiological and tumor promoting effects of estrogens [29].

The aim of this study is to define the impact of E4 on breast cancer growth. We investigated its effect on several in vitro and in vivo breast cancer models using a large range of concentrations. Special attention was devoted on molecular mechanisms driving E4 effects.

\section{RESULTS}

\section{$\mathrm{E} 4$ is weaker than $\mathrm{E} 2$ to increase the growth of ERo-positive breast cancer cells}

We first compared the effect of E2 and E4 on the growth of MCF-7 breast cancer cells, which express ER $\alpha, E R \beta$ and GPER (Suppl. Figure 1). E2 tested at concentrations ranging from $1 \times 10^{-13}$ to $1 \times 10^{-4} \mathrm{M}$ induced a typical bell shaped dose-response curve, with a maximal response of 2.2-fold reached at $1 \times 10^{-11} \mathrm{M}$ (Figure 1A). High concentrations of E2 $\left(\geq 1 \times 10^{-5} \mathrm{M}\right)$ caused a rapid decline in cell growth, indicative of cytotoxicity. At 1x10${ }^{11} \mathrm{M}, \mathrm{E} 4$ did not increase MCF-7 cell growth (Figure 1B), but a 1,000 -times higher concentration $\left(1 \times 10^{-8} \mathrm{M}\right)$ was necessary to promote growth to the same extent than E2.

Dose-response curves for E2 and E4 recorded in the E-Screen assay (Figure 1C), also showed that E4 produced a weak agonistic activity compared to E2 with an EC50 of $4 \times 10^{-9} \mathrm{M}$ and a maximal mitogenic effect around $1 \times 10^{-}$ ${ }^{7} \mathrm{M}$, demonstrating a 200 times weaker capacity to induce MCF-7 BOS cell growth than E2 $\left(E C 50=2 \times 10^{-11} \mathrm{M}\right)$.

When used at a stimulating concentration (E2 $1 \times 10^{-9} \mathrm{M}$ and $\left.\mathrm{E} 41 \times 10^{-7} \mathrm{M}\right)$, both compounds increased MCF-7 cell growth in a similar time-dependent manner (Figure 1D). It is noteworthy to consider that such E4 pharmacological high doses would never be used in clinical setting.

We then evaluated the impact of E4 on breast cancer cell lines exhibiting different pattern of estrogen receptor expression (Suppl. Figure 1): T47D $(\mathrm{ER} \alpha+$, ER $\beta-$, GPER+), MDA-MB-231 (ER $\alpha-$, ER $\beta+$, GPER+) and SKBR3 (ER $\alpha-$, ER $\beta-$, GPER+) cells. After $72 \mathrm{~h}$ of treatment, E2 $\left(1 \times 10^{-9} \mathrm{M}\right)$ and E4 $\left(1 \times 10^{-7} \mathrm{M}\right)$ increased the growth of T47D cells similarly to what was seen for MCF-7 cells (Figure 1E). By contrast, E2 and E4 failed to stimulate the growth of MDA-MB-231 (Figure 1F) and SKBR3 cells (Figure 1G).

Altogether, these data support that E4 increases cell growth only at high concentrations and that ER $\alpha$ expression is required for this mitogenic activity.

\section{E4 increases cell growth by stimulating proliferation and preventing cell death}

Estrogens stimulate cell growth in ER $\alpha$-positive cells by increasing cell proliferation and reducing apoptosis [30]. To determine the impact of E4 on proliferation and cell death, a thymidine incorporation assay and a quantification of histone-complex DNA fragments were carried out on MCF-7 cells. As expected, E2 stimulated the proliferation of MCF7 cells (Figure 2A). A 100 times higher concentration of $\mathrm{E} 4$ was needed to achieve the same effect. Cells treated with E2 $\leq 1 \times 10^{-6} \mathrm{M}$ 
A
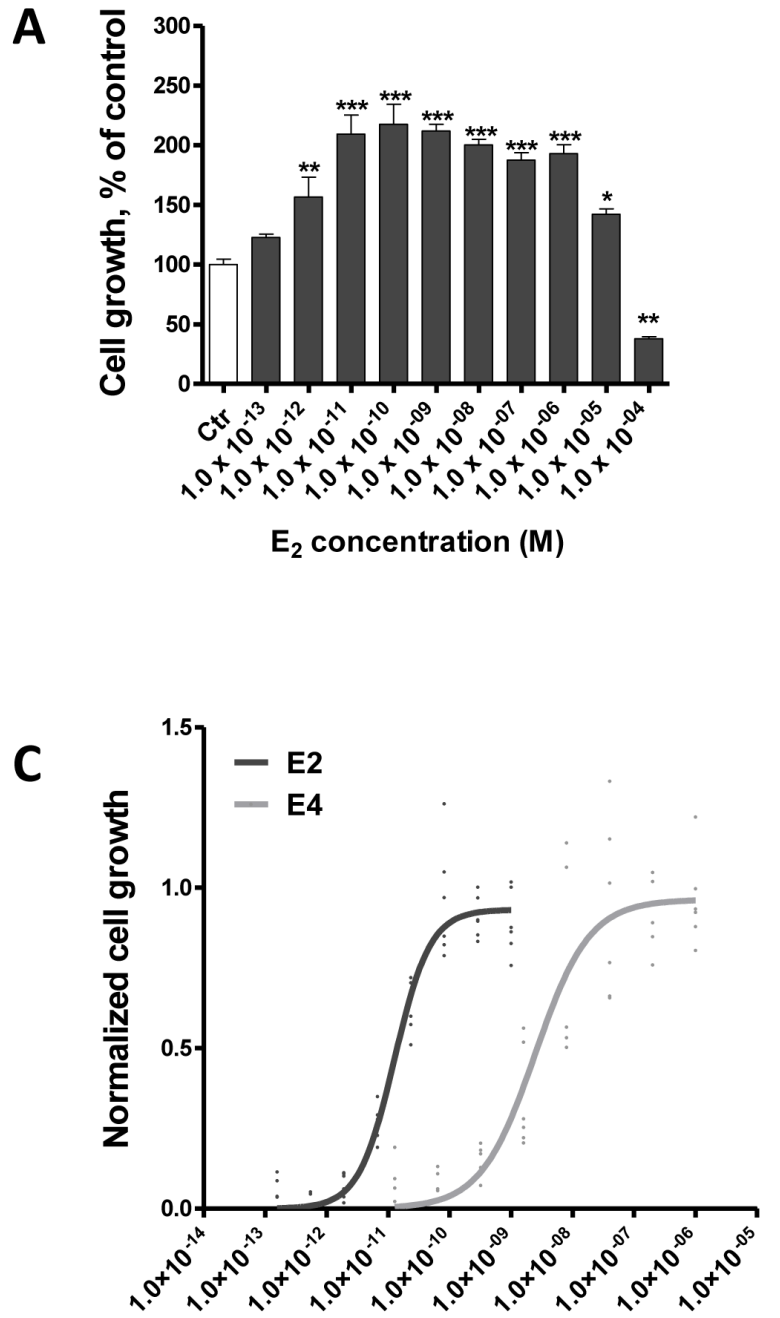

Concentration (M)

\section{B}
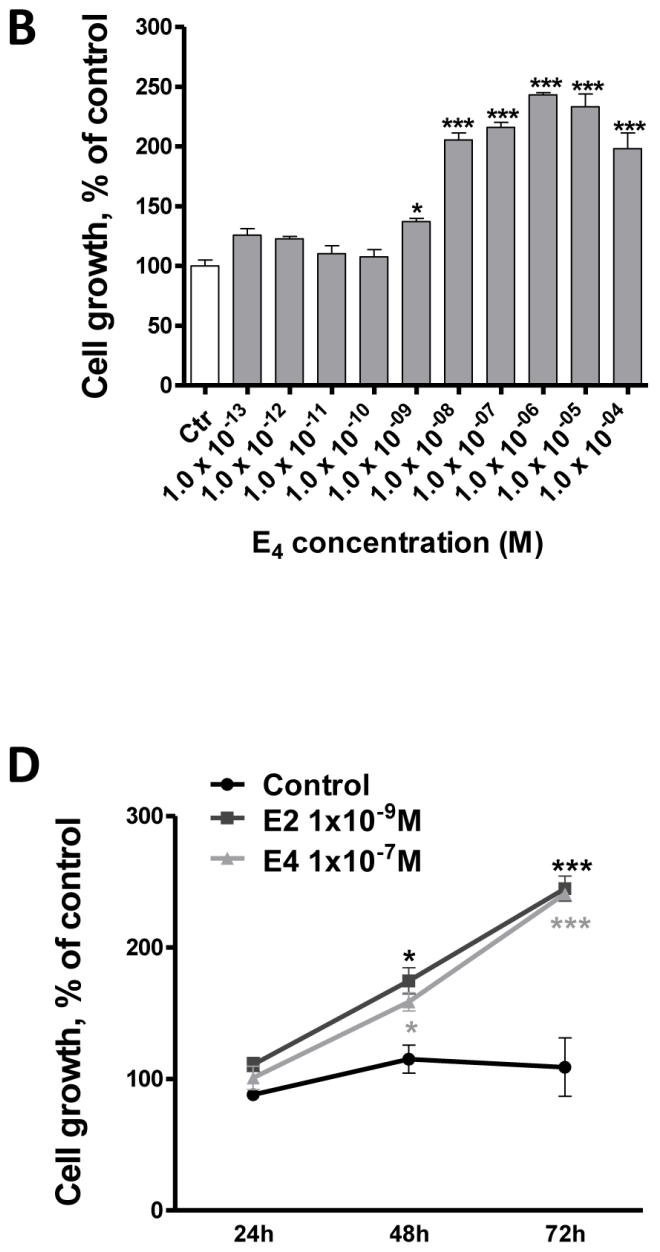

Duration of drug exposure
E

T47D

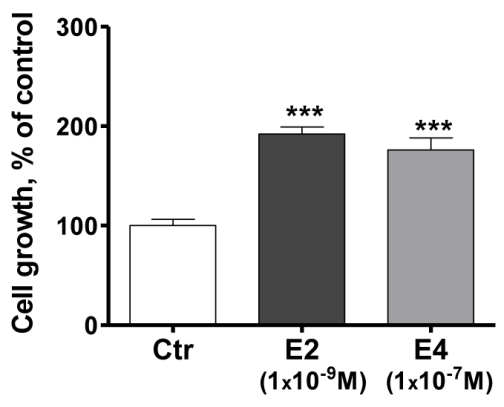

$\mathbf{F}$

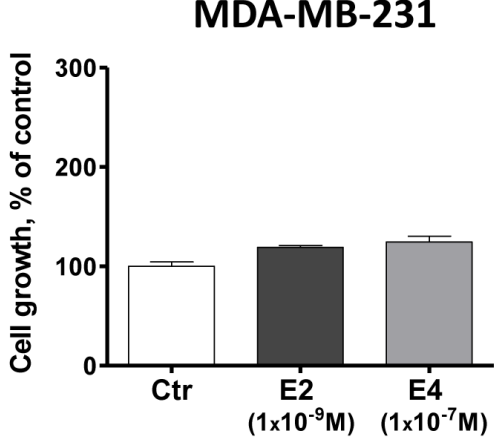

$\mathbf{G}$

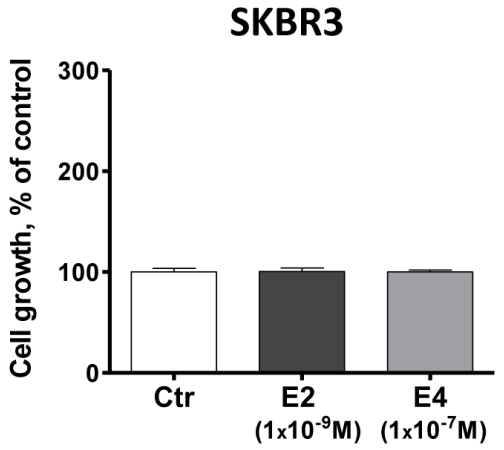

Figure 1: E4 is weaker than E2 in promoting the growth of breast cancer cells. A.-B., dose-dependent effect of E2 (A) and E4 (B) on the growth of MCF-7 cells. Cells were treated for 72 hours with vehicle (ctr) or increasing concentrations of E2 or E4. C., effect of E2 and E4 in the E-Screen assay. MCF-7 BOS cells were treated with increasing concentrations of E4 (grey curve) or E2 (black curve). Graph represents three independent experiments run in duplicate and shows experimental data (dots) with best fit regression curves. D., time-course experiment. MCF-7 cells were cultured for up to 3 days in presence of E2 $1 \times 10^{-9} \mathrm{M}$ (square), E4 1x10-7 M (triangle) or vehicle (control, circle). E.-G., growth of T47D (E), MDA-MB-231 (F) and SKBR3 (G) cells treated with vehicle (ctr), E2 1x10-9 M or E4 1x10-7 M. Data are represented as mean $\pm \operatorname{SEM}(n=5)$. *: $P \leq 0.05 ; * *: P \leq 0.01 ; * *: P \leq 0.001$ versus control group. 
A

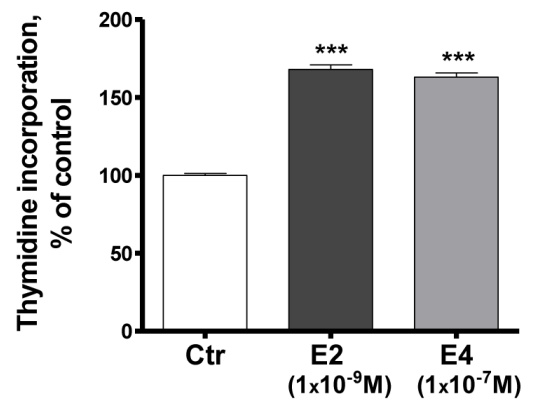

B

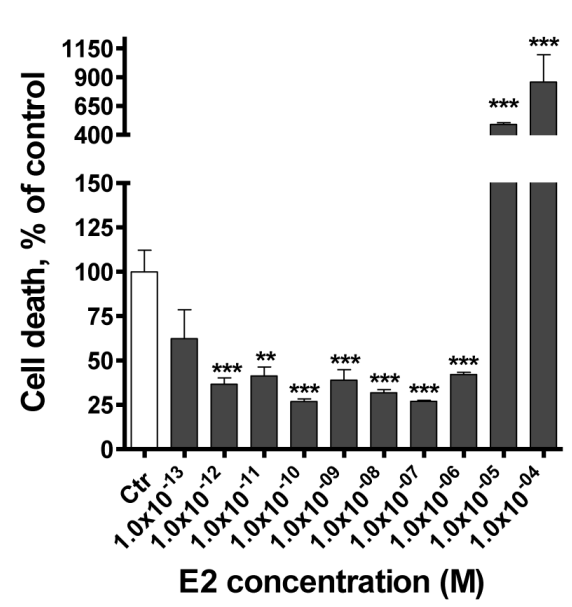

D

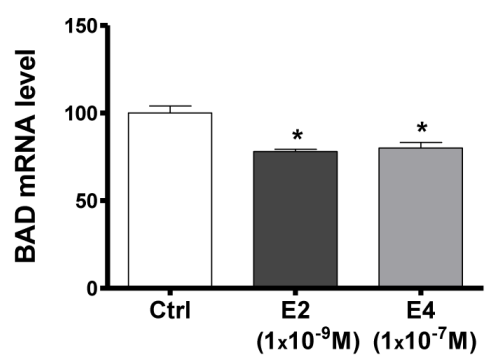

$\mathbf{F}$

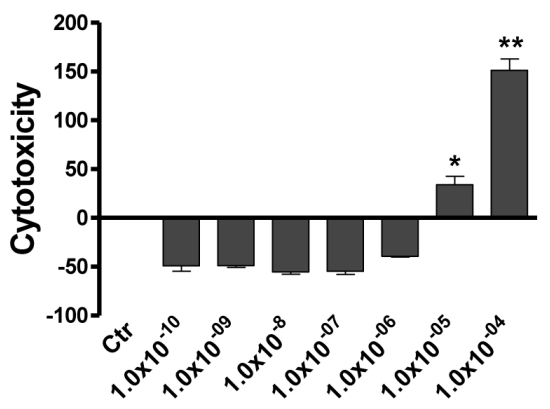

E2 concentration (M)
C

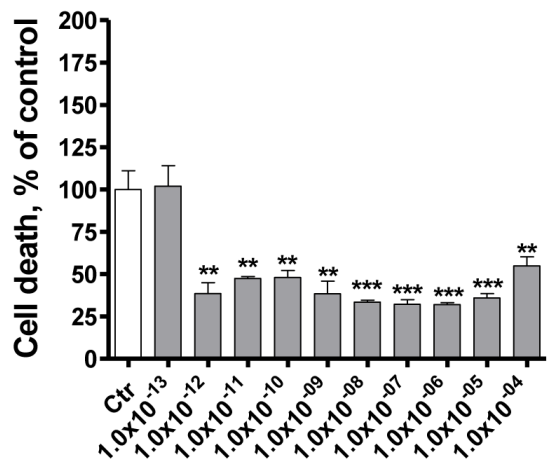

E4 concentration (M)

E

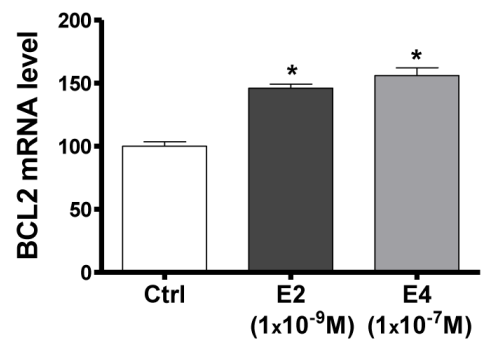

G

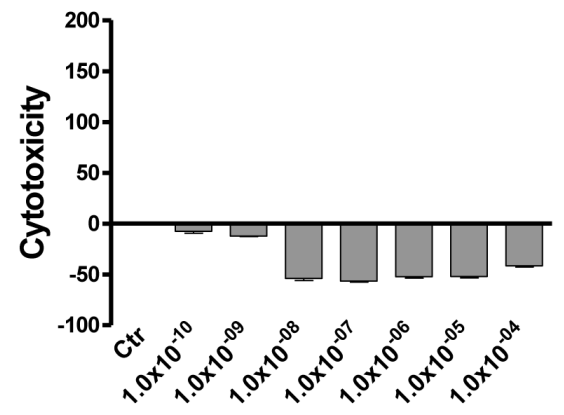

E4 concentration (M)

Figure 2: E4 increases cell proliferation and reduces apoptosis of breast cancer cells. A., proliferation of MCF-7 cells treated with vehicle (ctr), E2 $1 \times 10^{-9} \mathrm{M}$ or E4 $1 \times 10^{-7} \mathrm{M}$. Proliferation was evaluated using a thymidine incorporation assay after 72 hours of treatment. B.-C., Cell death level in MCF-7 cells treated for 72 hours with vehicle (ctr) or increasing concentrations of E2 (B) or E4 (C). D.E., quantitative RT-PCR analysis of pro-apoptotic gene $B A D(\mathrm{D})$ and anti-apoptotic gene $B C L 2$ (E) from MCF-7 cells treated with vehicle (ctrl), E2 $1 \times 10^{-9} \mathrm{M}$ or E4 $1 \times 10^{-7} \mathrm{M}$ during 6 hours. F.-G., cytotoxicity induced by increasing concentrations of E2 (F) or E4 (G) in MCF-7 cells after 72 hours of treatment. Data are represented as mean $\pm \operatorname{SEM}(n=3)$. *: $P \leq 0.05$; $^{* *}: P \leq 0.01$; ***: $P \leq 0.001$ versus control group. 
exhibited $\mathrm{a} \sim 60 \%$ lower level of cell death than control cells but at concentrations $>1 \times 10^{-6} \mathrm{M}$, E2 dramatically stimulated cell death (Figure 2B). In a similar way to E2, $\mathrm{E} 4$ reduced the cell death level in treated cells (Figure 2C). Interestingly, in contrast to E2, E4 did not induce cell death when used at high concentrations. In addition, both E4 $\left(1 \times 10^{-7} \mathrm{M}\right)$ and E2 $\left(1 \times 10^{-9} \mathrm{M}\right)$ significantly decreased the expression of the pro-apoptotic gene BAD (Figure 2D) and up-regulated the anti-apoptotic gene BCL2 (Figure 2E), supporting an impact on apoptosis..

A cytotoxicity test revealed that E2 concentrations ranging from $1 \times 10^{-10} \mathrm{M}$ to $1 \times 10^{-6} \mathrm{M}$ decreased $\mathrm{MCF}-7$ cytotoxicity, but that E2 was concentrations of $1 \times 10^{-5} \mathrm{M}$ and $1 \times 10^{-4} \mathrm{M}$ were cytotoxic (Figure $2 \mathrm{~F}$ ). E4 did not show any sign of cytotoxicity for concentrations up to $1 \times 10^{-4} \mathrm{M}$ (Figure 2G).

\section{E4 increases cell growth primarily via ERa}

Using tamoxifen, an ER $\alpha$ antagonist in the breast, and ICI 182 780, a pure ER $\alpha$ antagonist, we observed that the combinations of E4 with both antiestrogens decreased MCF-7 cell growth to level of untreated cells (Figure 3A). This observation confirms that the stimulating effect of $\mathrm{E} 4$ is mediated by ER $\alpha$. ER $\alpha$ is described to be activated by phosphorylation on key serine residues among which Ser118, the major phosphorylation site when the receptor is activated by estrogens, and Ser167 phosphorylated through the EGF/EGFR pathways [31]. The stimulation of MCF-7 cells with E2 $\left(1 \times 10^{-9} \mathrm{M}\right)$ or E4 $\left(1 \times 10^{-7} \mathrm{M}\right)$ led to a robust phosphorylation of Ser118 and to a weak phosphorylation of Ser167 (Figure 3B), highlighting the activation of ER $\alpha$ by these compounds. While E4 was unable to stimulate the proliferation of SKBR3 cells which express GPER but not ER $\alpha$, G15, a reported GPER antagonist, partially decreased the E2- and E4-induced MCF-7 cell growth (Figure 3C).

These data confirm our above observations (Figure 1) that $E R \alpha$ is the predominant receptor mediating the mitogenic effects of E4. They also suggest a possible contribution of GPER to this process. It has been indeed suggested that GPER may facilitate membrane-initiated steroid signaling under limited circumstances [32].

\section{E4 elicits estrogenic effect by increasing transcriptional activity of ERa}

To assess the impact of E4 on the activation and binding of ER $\alpha$ to ERE, we performed a luciferase reporter gene assay based on T47D-KBluc cells in presence of increasing concentrations of E2 or E4. As expected, E2 induced a strong ERE-Luc transactivation in T47D cells with an EC50 value of $1 \times 10^{-11} \mathrm{M}$. E4 also stimulated ERELuc transactivation, but the curve was shifted to higher concentrations, with an EC50 of $1 \times 10^{-8} \mathrm{M}$, and a maximal effect reached at $1 \times 10^{-7} \mathrm{M}$ (Figure $4 \mathrm{~A}$ ). Similar results were obtained by using MCF-7 cells (Suppl. Figure 2). This E4-dependent transcriptional activity was completely abrogated by the ER $\alpha$ antagonist ICI 182,780 (Figure 4B), validating the specificity of the above results.

A

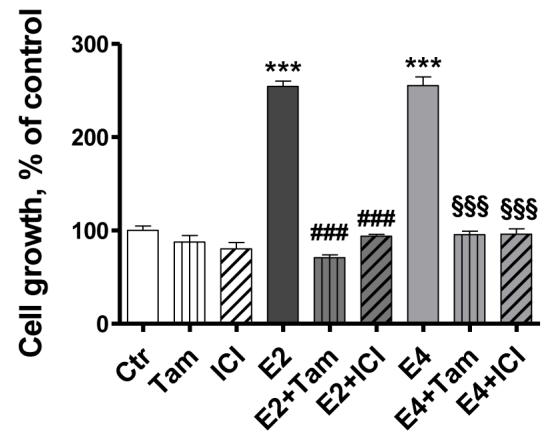

B

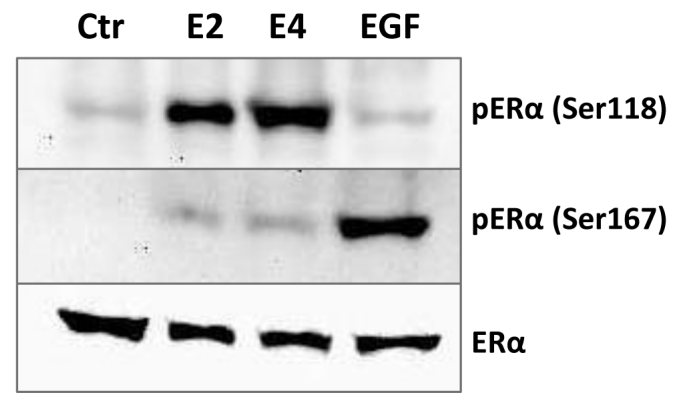

C

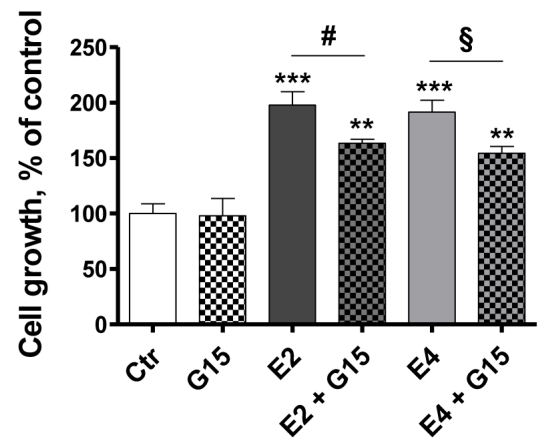

Figure 3: E4 stimulates cell growth primarily via ERo. A., MCF-7 cell growth in the presence of antiestrogens fulvestrant and tamoxifen. Cells were exposed to vehicle (ctr), $1 \times 10^{-7} \mathrm{M}$ fulvestrant (ICI), $1 \times 10^{-7} \mathrm{M}$ tamoxifen (tam), $1 \times 10^{-9} \mathrm{M}$ $\mathrm{E} 2,1 \times 10^{-7} \mathrm{M}$ E4 or combination of estrogens and antiestrogens. B., representative western blot of estrogen receptor alpha phosphorylation after a treatment of 30 minutes with vehicle (ctr), E2 $1 \times 10^{-9} \mathrm{M}$, E4 $1 \times 10^{-7} \mathrm{M}$ or EGF $100 \mathrm{ng} / \mathrm{ml}$. C., MCF-7 cell growth in the presence of G15 $1 \times 10^{-6} \mathrm{M}$, a GPER antagonist. Cell growth was evaluated after 72 hours of treatment. Data are represented as mean $\pm \operatorname{SEM}(n=5) .{ }^{*}, P \leq 0.05 ; * *, P \leq 0.01$; $* * *, P \leq 0.001$ versus control group. \#, $P \leq 0.05$; \#\#\#, $P \leq 0.001$ versus E2 group. $\S, P \leq 0.05 ; \S \S \S, P \leq 0.001$ versus E4 group. 
A

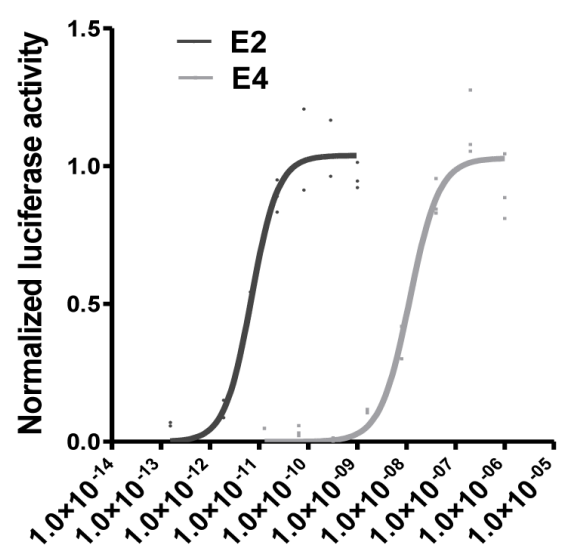

Concentrations (M)

C

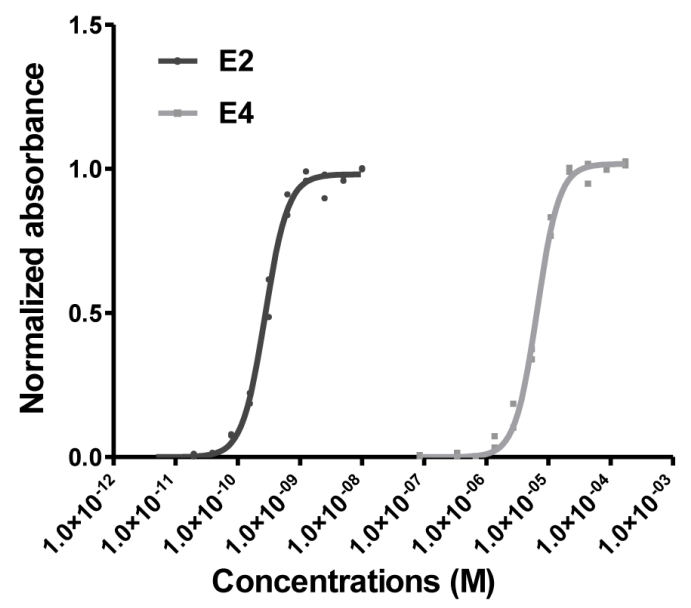

$\mathbf{F}$
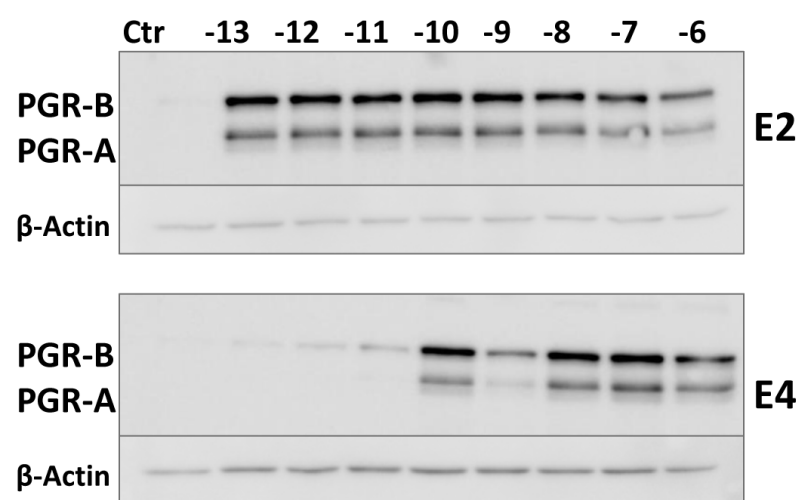

B

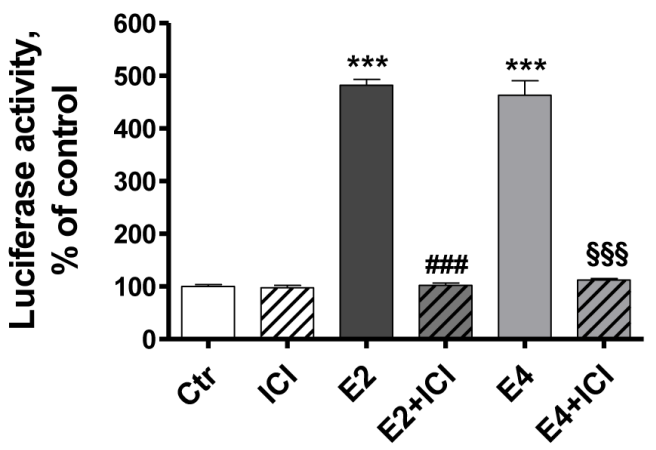

D

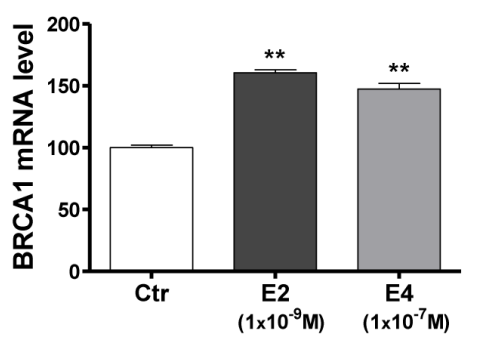

E

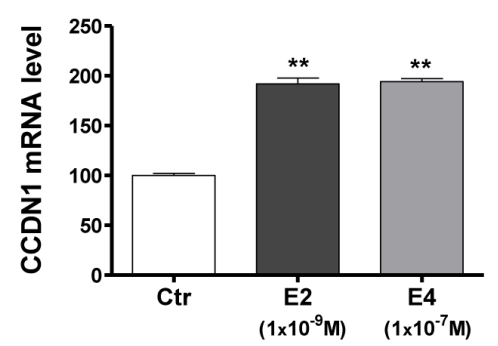

G

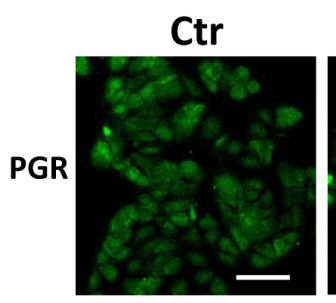

E2

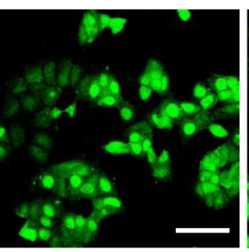

E4



Figure 4: E4 enhances transcriptional activity of ER $\boldsymbol{\alpha}$. A., normalized effect of increasing concentrations of E2 (black curve) and E4 (grey curve) on ERE-luciferase reporter activity in T47D-KBluc cells. B., normalized luciferase activity of T47D-KBluc cells treated with vehicle (ctr), ICI 182,780 $\left(1 \times 10^{-7} \mathrm{M}\right)$, E2 $\left(1 \times 10^{-9} \mathrm{M}\right)$, E4 $\left(1 \times 10^{-7} \mathrm{M}\right)$ or a combination of estrogen and ICI 182,780. ERE-luciferase reporter activity was measured after 24 hours. C., normalized effect of increasing concentrations of E2 (black curve) and E4 (grey curve) on absorbance in the recombinant yeast estrogen screen. Graph shows experimental data (dots) with best fit regression curves. D.-E., quantitative RT-PCR analysis of $B R C A 1$ (D) and CCDN1 (E) genes from MCF-7 cells treated with vehicle (ctr), E2 1x10-9 M or E4 1x 10${ }^{7} \mathrm{M}$ during 6 hours. F.-G., progesterone receptor (PGR) induction highlighted by western blot (F) in MCF-7 cells treated with increasing concentrations of E2 or E4 (from $1 \times 10^{-13}$ to $1 \times 10^{-6} \mathrm{M}$ ) and by immonufluochemistry $(\mathrm{G})$ after treatment with vehicle (ctr), E2 $1 \times 10^{-9} \mathrm{M}$ or E4 $1 \times 10^{-7} \mathrm{M}$ during 48 hours. Scale bar $=50 \mu \mathrm{m}$. Data are represented as mean \pm SEM. $* *, P \leq 0.01 ; * * *, P \leq 0.001$ versus control group. $\# \#, P \leq 0.001$ versus E2 group. $\S \S \S, P \leq 0.001$ versus E4 group. 
The weaker capacity of E4 to induce the binding of $\mathrm{ER} \alpha$ to ERE was confirmed in a second model: the Yeast Estrogen Screen (Figure 4C), which is based on the ability of a compound to stimulate the expression of $\beta$-galactosidase in yeast by activating ER $\alpha$. The normalized data showed that E4 had a potency of approximately 10,000 times less than E2 to activate the receptor and promote $\beta$-galactosidase production in the yeast.

We next investigated the capacity of E4 to promote non-classical nuclear effects by assessing the expression of genes that do not harbor ERE in their promoter region: $B R C A 1$ and $C C D N 1$. These genes are thought to be regulated by the recruitment of $\mathrm{ER} \alpha$ to $\mathrm{AP}-1$ or $\mathrm{Sp} 1$ sites in the promoter region [33, 34]. Following 6 hours of incubation, both E4 $\left(1 \times 10^{-7} \mathrm{M}\right)$ and E2 $\left(1 \times 10^{-9} \mathrm{M}\right)$ upregulated $B R C A 1$ and $C C D N 1$ mRNA (Figure 4D-4E).

Finally, to further demonstrate the transcriptional activation of $\operatorname{ER} \alpha$, we evaluated the induction of the progesterone receptor (PGR) protein, a well described estrogen-dependent process [35]. E4 led to a significant up-regulation of PGR in MCF-7 cells. At least $1 \times 10^{-10} \mathrm{M}$ of E4 was required while E2 achieved a maximal effect at a concentration as low as $1 \times 10^{-13} \mathrm{M}$ (Figure $4 \mathrm{~F}$ ). The induction of PGR in MCF-7 cells by E2 $\left(1 \times 10^{-9} \mathrm{M}\right)$ and E4 $\left(1 \times 10^{-7} \mathrm{M}\right)$ was also highlighted by immunofluochemistry (Figure 4G).

Altogether these data support that E4 is a weak inducer of $\mathrm{ER} \alpha$ transcriptional activity by activating both classical and non-classical nuclear effects with a lower efficiency than E2.

\section{E4 activates extra-nuclear signaling cascades in breast cancer cells}

The extra-nuclear effects of E2 on breast cancer rely on the activation of MAPK and PI3K/AKT pathways
A

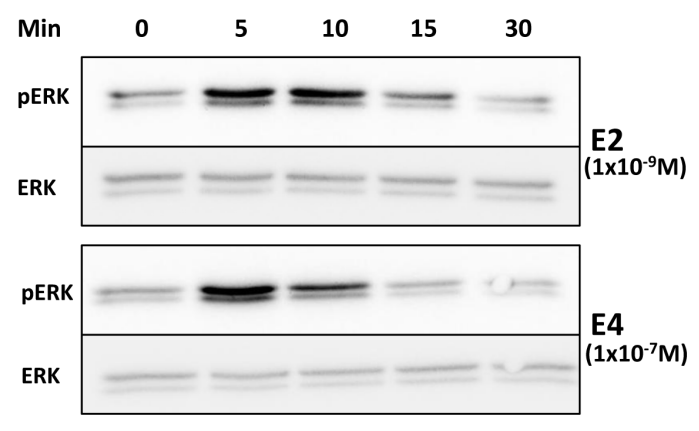

C

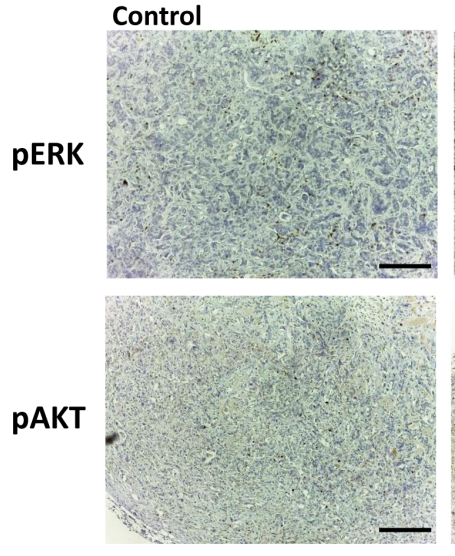

E2

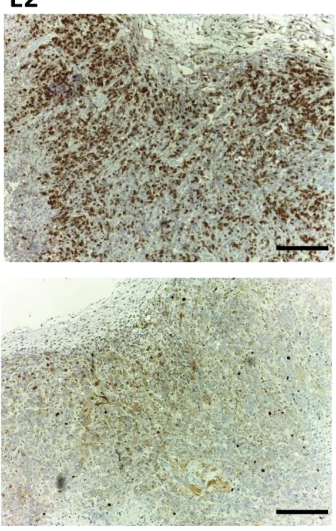

B
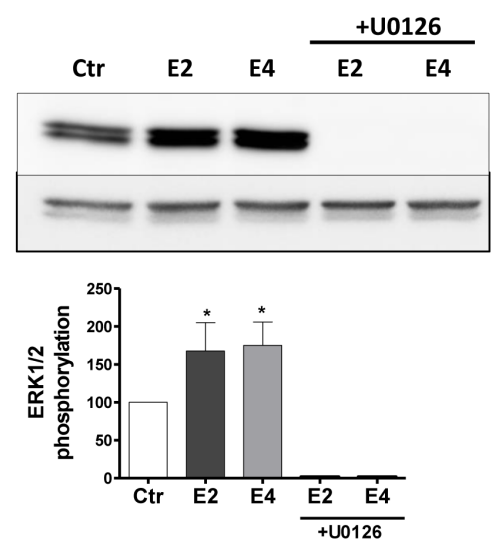

E4

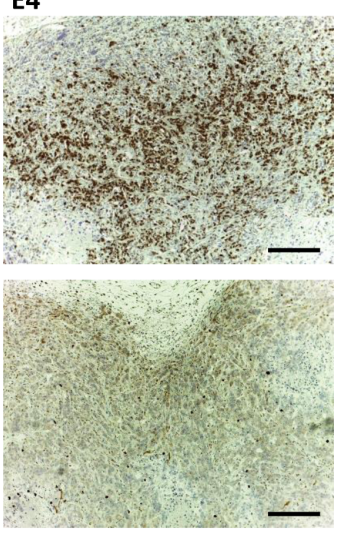

Figure 5: E4 activates extra-nuclear signaling pathways. A., representative western blot of ERK1/2 phosphorylation in MCF-7 cells treated with $1 \times 10^{-9} \mathrm{M}$ E2 or $1 \times 10^{-7} \mathrm{M}$ E4 during 5, 10, 15 and 30 minutes. B., representative western blot and quantitative analysis of ERK1/2 phosphorylation in MCF-7 cells treated with vehicle (ctr), $1 \times 10^{-9} \mathrm{M}$ E2, $1 \times 10^{-7} \mathrm{M}$ E4 or combination of estrogens and $1 \times 10^{-5} \mathrm{M}$ U0126 during 5 minutes. All treatments were performed in the presence of a same concentration of vehicle (ethanol 0,1\%) C., IHC staining of pERK and pAKT on MCF-7 tumors collected from mice treated with vehicle (control), E2 (provided by pellet) or E4 (3mg/kg/day) during 5 weeks. *, $P \leq 0.05$ versus control group. Scale bar $=200 \mu \mathrm{M}$. 
$[36,37]$. Like E2 $\left(1 \times 10^{-9} \mathrm{M}\right), \mathrm{E} 4\left(1 \times 10^{-7} \mathrm{M}\right)$ increased the phosphorylation of ERK $1 / 2$ in a fast and transient manner, with a maximal activation seen after 5 min followed by a decline within 10 minutes (Figure 5A). U0126, an inhibitor of the upstream MEK1/2, completely abolished ERK1/2 phosphorylation attesting that the observed phosphorylation was induced by MEK in MCF-7 cells (Figure 5B). We also observed an increase in ERK1/2 and AKT phosphorylation in vivo in MCF-7 tumors resected from mice treated with E4 or E2 during 5 weeks (Figure 5C).

These results support that, in addition to nuclear effects, E4 is also able to activate extra-nuclear ERK1/2 and $\mathrm{PI} 3 \mathrm{~K} / \mathrm{AKT}$ pathways.

A

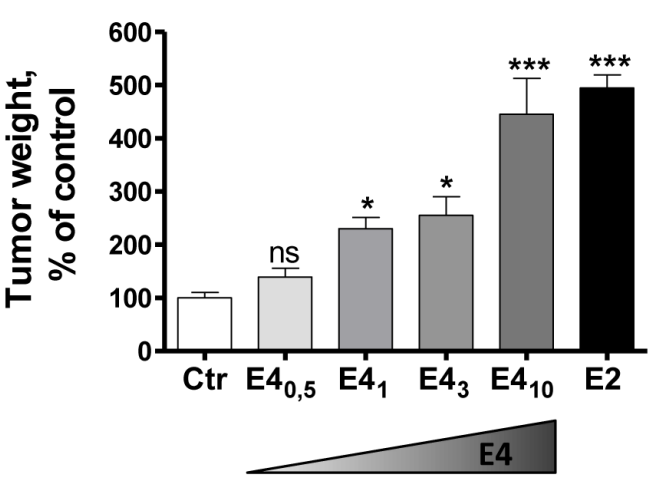

C

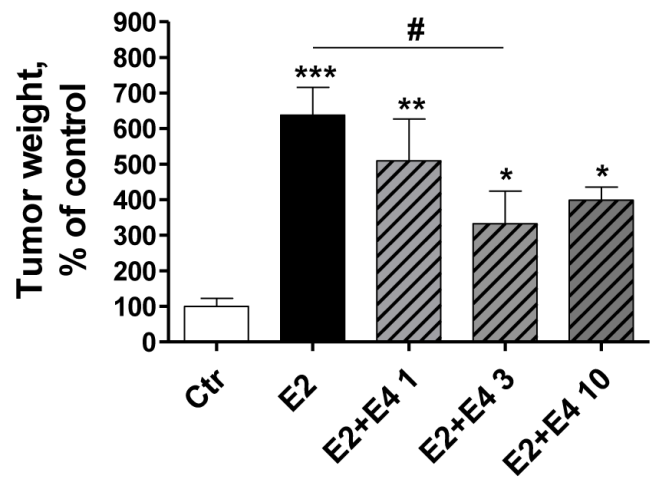

E4 increases breast tumor growth in vivo only at high concentrations, and antagonizes E2dependent effect

An estrogen supplementation is necessary for the growth of MCF-7 and the formation of tumor in vivo. To determine if E4 could achieve the same effect than E2, ovariectomized immunodeficient mice implanted with MCF-7 cells received a daily oral treatment of E4 $(0.5,1,3$ or $10 \mathrm{mg} / \mathrm{kg} /$ day $)$ or E2 (3 mg/kg/day). After 5 weeks of treatment, E2 promoted tumor growth and tumor weights were 5-fold increased compared to the untreated group (Figure 6A). However, no significant difference was observed between untreated control group and mice

B

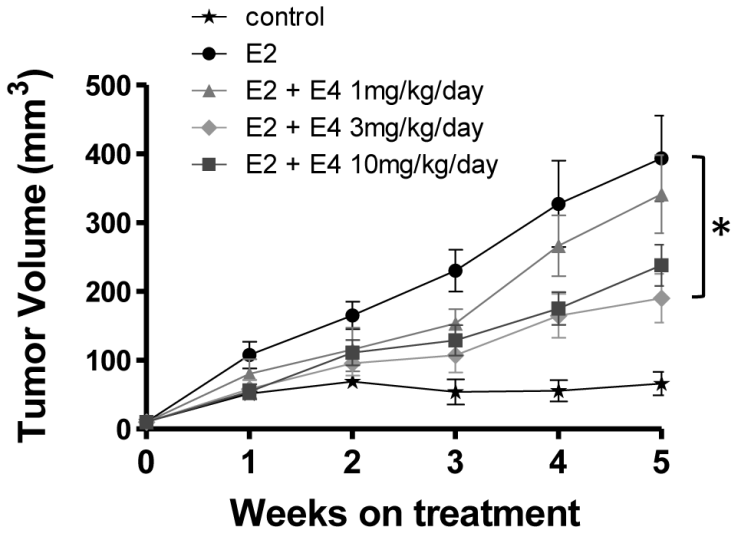

D

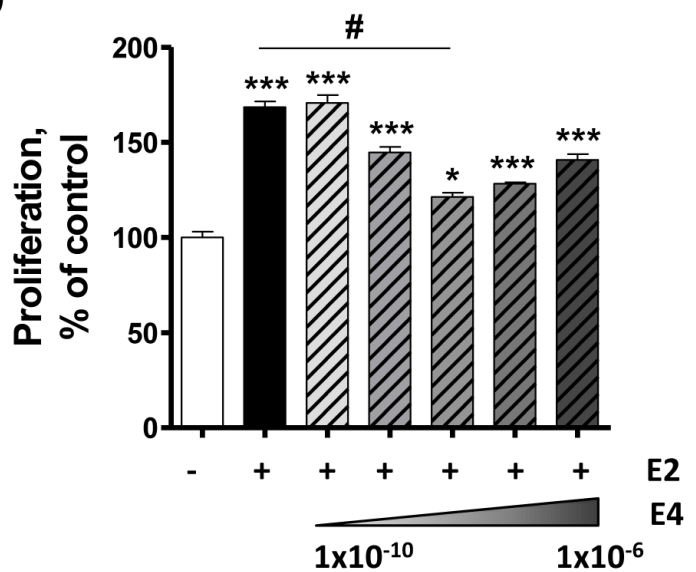

Figure 6: E4 moderately increases tumor growth in vivo, but antagonizes E2-dependent effect. A., Normalized weight of MCF-7 tumors resected from immunodeficient mice after 5 weeks of treatment. Mice were treated orally with vehicle (ctr), E2 (3mg/kg/ day) or E4 $(0.5 \rightarrow 10 \mathrm{mg} / \mathrm{kg}$ /day). B., In vivo growth curve of MCF-7 tumors in immunodeficient mice treated with vehicle (control, stars), estradiol only (E2, circle) or with a combination of E2 and E4 1 (triangle), 3 (diamond) or 10 (square) $\mathrm{mg} / \mathrm{kg} / \mathrm{day} \mathrm{during} 5 \mathrm{weeks}$. C., normalized weight of MCF-7 tumors collected from nude mice after 5 weeks of treatment with E2 alone or combinations of E2 and E4. D., proliferation of MCF-7 cells treated with vehicle, E2 $1 \times 10^{-10} \mathrm{M}$ alone or with different combinations of E2 and E4. Increasing concentrations of E4 (from $1 \times 10^{-10}$ to $\left.1 \times 10^{-6} \mathrm{M}\right)$ were added to a fixed concentration of E2 $\left(1 \times 10^{-10} \mathrm{M}\right)$ and proliferation was evaluated with a thymidine incorporation assay after 72 hours of treatment. Data are represented as mean $\pm \operatorname{SEM}(n=5)$. *,$P \leq 0.05 ; * *, P \leq 0.01 ; * * *, P \leq 0.001$ versus control group. \#, $P \leq 0.05$ versus $\mathrm{E} 2$ group. 
treated with E4 $0.5 \mathrm{mg} / \mathrm{kg} /$ day. E4 was as efficient as E2 in promoting tumor growth only at the dose of $10 \mathrm{mg} / \mathrm{kg} /$ day.

We then analyzed the effect of a combined treatment of E2 and E4 on MCF-7 tumor growth. Ovariectomized mice implanted with MCF-7 cells and with an E2 pellet received a daily oral treatment of $\mathrm{E} 4(1,3$ or $10 \mathrm{mg} / \mathrm{kg} /$ day) during 5 weeks (Figure 6B). In these conditions, E4 antagonized E2-induced tumor growth in a dosedependent manner. Exposure to the combination E2+E4 decreased the tumor volume and tumor weight by $\sim 50 \%$ compared to mice exposed to E2 alone (Figure 6B-6C). This partial anti-estrogenic effect of $\mathrm{E} 4$ in the presence of E2 was also observed in vitro on MCF-7 cell proliferation. This effect became maximal when E4 was at least 100 times more concentrated than E2 (Figure 6D).

Altogether, these results indicate that E4 used alone acts as a weak estrogen and stimulates the growth of MCF7 tumor in vivo only at high concentrations. Interestingly, at these concentrations, E4 partially antagonized the protumoral effect of E2.
A

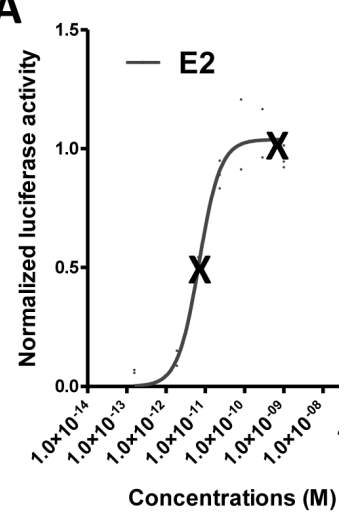

D

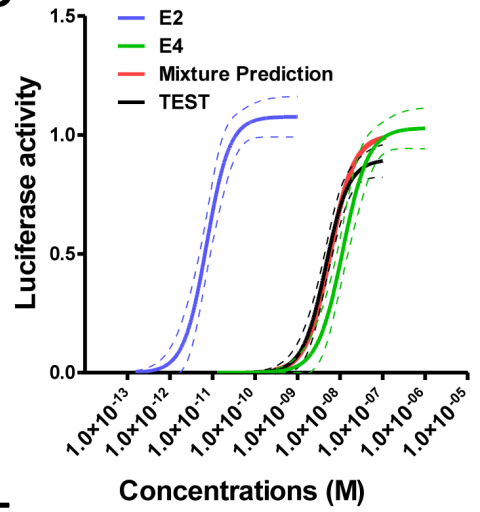

F

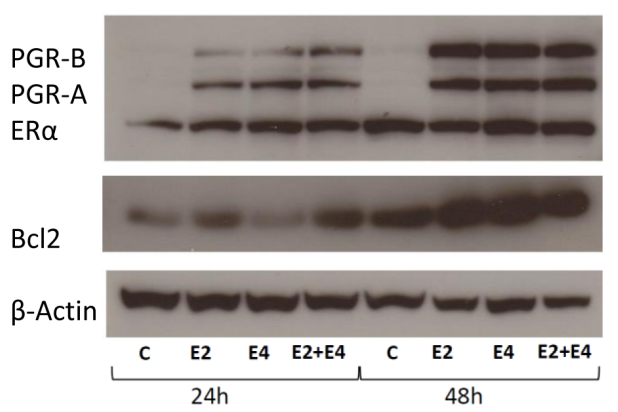

B

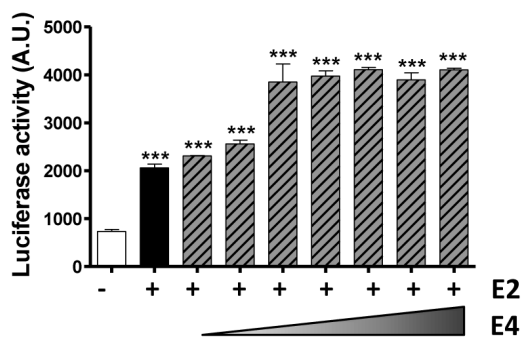

E
C

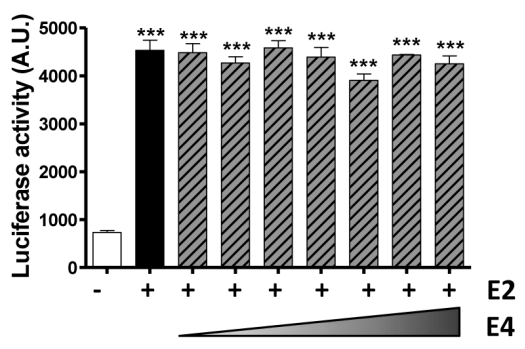

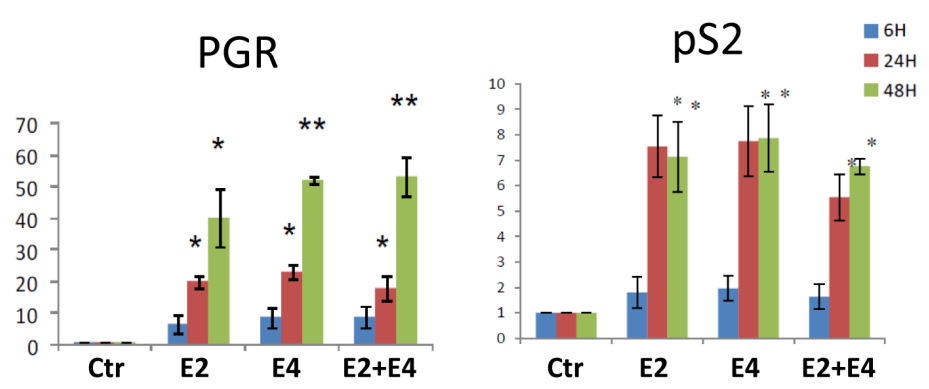

G
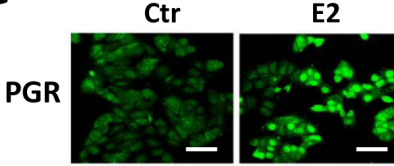

E4 E2+E4

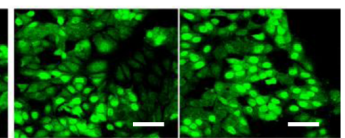

$E R \alpha$
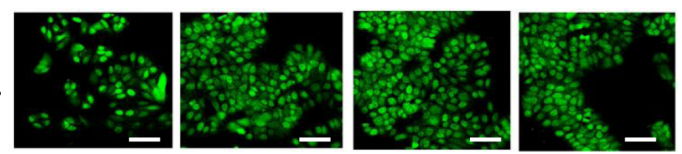

Figure 7: Impact of the combination E2 + E4. A.-C., effect of the combination E2 + E4 in the ERE-luciferase reporter activity. T47D-KBluc cells were treated with two fixed concentrations of E2 (A): $1 \times 10^{-11} \mathrm{M}(\mathrm{B})$ or $1 \times 10^{-9} \mathrm{M}(\mathrm{C})$ in combination with increasing concentrations of E4 (from $1 \times 10^{-11}$ to $1 \times 10^{-5} \mathrm{M}$ ). D, Mixture effect prediction on the ERE-luciferase reporter activity. Prediction curve (red) was calculated from separate E2 (blue) and E4 (green) curves using dose addition model. The prediction was then tested experimentally (TEST curve, black). Graph shows regression curves and their 95\% confidence belts (dotted lines). E., quantitative RT-PCR analysis of $P G R$ and PS2 genes from MCF-7 cells treated with E2 $1 \times 10^{-8} \mathrm{M}$, E4 $1 \times 10^{-6} \mathrm{M}$ or vehicle (ctr) during 6, 24 or 48 hours. F., representative western blot of PGR, ER $\alpha, \mathrm{BCL} 2$ and $\beta$-actine after treatment with E2 $1 \times 10^{-8} \mathrm{M}, \mathrm{E} 41 \times 10^{-6} \mathrm{M}$ or E2+E4 during 24 or 48 hours. G., immonufluochemistry of PGR and ER $\alpha$ in MCF-7 cells after treatment with vehicle (ctr), E2 $1 \times 10^{-8} \mathrm{M}$, E4 1x10-6 M or E2+E4 during 48 hours. Scale bar $=50 \mu \mathrm{m} . *, P \leq 0.05 ; * *, P \leq 0.01 ; * *, P \leq 0.001$ versus control group. 


\section{E4 does not antagonize suppress the nuclear ER $\alpha$ actions}

We demonstrated above that E4 induces both nuclear and extra-nuclear signaling, albeit less efficiently than E2. Thus, trying to understand the mechanisms underlying the antagonistic effects of E4 on E2, we assessed the impact of E2+E4 combination on ERE-dependent activity of ER $\alpha$. Increasing concentrations of E4 were combined with two different concentrations of E2 $\left(1 \times 10^{-11} \mathrm{M}\right.$ and $\left.1 \times 10^{-9} \mathrm{M}\right)$ inducing submaximal and maximal effects, respectively (Figure 7A). In these conditions, E4 failed to antagonize the effects of E2 on ERE-Luc transactivation induction in T47D-KBluc cells. On the contrary, a cumulative effect of both compounds was observed when E2 was used at the submaximal concentration to reach maximal ERE activity (Figure 7B). No effect of E4 was observed on luciferase activity when E2 was used at a dose that already induced maximal ERE activity (Figure 7C). Same results were obtained using ERE-Luc transfected MCF-7 cells line (Suppl. Figure 3).

Further experiments were conducted by predicting and testing the effect of a binary mixture between E2 and E4. The prediction was calculated with dose addition, a commonly used concept in toxicology for the prediction of chemical mixture additive effects [38]. The prediction was then tested experimentally. Data showed that the predicted combination effect agreed very well with the experimentally observed data (Figure 7D) confirming that E2 and E4 do not have any antagonistic effect on ER $\alpha$ binding to ERE when they are combined. Moreover, the combination of E2+E4 failed to modulate the E2-induced expression of genes harboring ERE in their promoter region, such as $p S 2, B C L 2$ and $P G R$ at mRNA and/or protein level (Figure 7E-7G).

These data clearly demonstrate that E4 does not antagonize the nuclear actions induced by E2.

\section{DISCUSSION}

The identification of new estrogenic compounds for MHT that selectively preserve the beneficial effects of estrogens while reducing their unwanted side effects, such as breast cancer promotion, is largely needed. Several evidences have suggested that E4 could act as a SERM [9-16]. However, its impact on breast cancer remains controversial and poorly understood since it is reported to be either an estrogen or an anti-estrogen. The preclinical results presented in this study indicate a dose-dependent dual weak estrogenic/anti-estrogenic activity of E4 on breast cancer and delineate a safe therapeutic window for menopause treatment.

Below 10 nM, E4 does not increase breast cancer growth, while E2 already causes a maximal stimulation. On the other hand, when used at concentrations higher than $10 \mathrm{nM}$, E4 exhibits an estrogenic activity by promoting breast cancer cell growth in line with previous in vitro studies $[19,20]$. It is important to consider that doses of E4 necessary to elicit such estrogenic effect on malignant breast cells are high pharmacological doses that would not be used for therapeutic purposes. Interestingly, E4 also presents an antitumor activity by reducing the strong mitogenic effect induced by E2, with a maximal antagonist effect seen when the concentration ratio E4/ E2 is equal to 100. Our findings can contribute to explain that high doses of E4 suppress mammary tumors induced by DMBA in rats [18]. This unique dual activity of E4 observed on breast cancer is also in line with promising data we previously reported on the reduced impact of E4 on normal mammary gland proliferation [17].

Preclinical studies have demonstrated that $0.3 \mathrm{mg}$ $\mathrm{E} 4 / \mathrm{kg} /$ day abolishes hot flushes in a rat model [11] and that $0.5 \mathrm{mg} E 4 / \mathrm{kg} /$ day elicits bone-sparing effects [12]. Moreover, in women, a daily oral dose of $2 \mathrm{mg}$ E4 ( $0.03 \mathrm{mg} / \mathrm{kg} /$ day) has an estrogenic effect on vaginal cytology while having a neutral protective effect on endometrial proliferation (Foidart \& Coelingh Bennink, congress of International Menopause Society 2014, personal communication). Notably, in our experimental conditions, these E4 doses failed to promote breast tumor growth. While the stimulation of breast cancer growth by E4 requires doses 100 to 1000 -fold higher than E2, E4 doses that are only 2-4 times higher than E2 abrogate efficiently the clinical symptoms of menopause in other target tissues (brain and vaginal keratinocytes). These data clearly highlight that E4 could be effective in women for the relief of menopausal symptoms at doses associated with no or limited impact on the breast, suggesting a large window of therapeutic safety.

The properties of E4 concerning cell proliferation and apoptosis pointed out in this work are in line with previous studies showing that estrogens promote breast cancer not only by stimulating cell proliferation but also by impacting the apoptotic pathways [30]. Nevertheless, our results diverge from the observations of Singer [21] reporting an increase of apoptosis in tumor of women treated during 14 days with $20 \mathrm{mg}$ E4 $(\sim 0.3 \mathrm{mg} / \mathrm{kg} /$ day $)$. As pointed out by the authors, this study was a small exploratory trial in which immunohistochemical analyses were conducted on a limited number of breast cancer samples. In contrast to E2, E4 is not cytotoxic even at concentrations higher than $1 \times 10^{-6} \mathrm{M}$, suggestive of a good tolerability. This observation is in agreement with the high E4 concentrations naturally found in the amniotic fluid and in the fetal and maternal plasma during pregnancy rising to $60 \mathrm{nM}$ and evidently safe for the fetus and the mother [39].

Our results clearly demonstrate that ER $\alpha$ is necessary to drive the mitogenic effect of E4 on breast cancer growth. Since $70 \%$ of breast cancers are diagnosed positive for $\mathrm{ER} \alpha$, this observation further underlines the crucial need to precisely characterize the impact of E4 
on breast cancer before any clinical use for MHT. The contribution of GPER to estrogen-induced signaling in breast cancer remains a matter of debate. Some studies report a contribution of GPER in the signaling induced by E2 [40] and in the proliferation of normal and malignant breast [41], although other reports failed to demonstrate this kind of observations [42]. In our experimental conditions, we observed that GPER was not sufficient to induce breast cancer cell growth. However, preliminary evidences suggest that it could partially contribute to this effect and to E4-induced signaling. One possibility is that E4 binds and activates ER $\alpha$, and this communicates to membrane localized GPER. This specific controversial issue oversteps the purpose of this study and will have to be addressed with appropriates tools since the possible involvement of GPER in E4 signaling suggested here, only relies on the specificity of G15 as a GPER antagonist.

Mechanistically, we demonstrate that E4 induces both nuclear and extra-nuclear signaling pathways. This agonistic profile of E4 on nuclear ER $\alpha$ activation observed in breast cancer is consistent with previous in vivo experiments performed on three recognized nuclear ER $\alpha$-dependent processes showing that high doses of E4 promote uterine gene expression, endometrial proliferation and prevention of atheroma [13]. The antagonistic activity exerted by E4 on E2-dependent breast cancer growth is clearly not mediated by a modulation of these ER $\alpha$ nuclear actions. This corroborates the observation that E4 fails to antagonize E2-dependent uterotrophic effects driven by $\mathrm{ER} \alpha$ nuclear actions [13]. In contrast, E4 antagonizes E2 extra-nuclear effects in the endothelium resulting in an inhibition of eNOS phosphorylation and NO release [13]. In breast cancer cells, we previously reported that a 5 minutes stimulation with either E2 or E4 significantly stimulated the cytoplasmic interaction between ER $\alpha$ and Src. Rather surprisingly, the combination E2+E4 had no stimulatory effect on this interaction [13]. In addition, E4 decreases the E2-induced moesin phosphorylation, leading to a subsequent reduction of cell migration [22]. The molecular mechanisms driving extra-nuclear actions of estrogens are far from being fully understood. The downstream targets regulated by the membrane-associated form of $\mathrm{ER} \alpha$ involve various post-transcriptional modifications that highly differ between cell types. In addition, the number and variety of signaling proteins involved convey specificity to the estrogen signaling in a cell- and context-dependent fashion and result in differential cell activities [26]. Thus, it is important to consider a possible involvement of GPER and other signaling molecules in modulating E4 action on malignant breast cells.

In summary, a major issue to improve postmenopausal women's health is to identify new compounds that present an estrogenic effect on the vagina, the bone, cardiovascular and central nervous systems, while having minimal impact on the breast. The exclusive dual weak estrogenic/anti-estrogenic activity of E4, through tissue-specific crosstalk between nuclear and extra-nuclear signaling pathways, opens promising possibilities. There is, of course, a large frontier between preclinical mechanistic studies and clinical performance of any new drug. Therefore, clinical studies are now needed to confirm the efficacy and the safety of E4 to relieve menopausal symptoms.

\section{MATERIALS AND METHODS}

\section{Chemicals, drugs and antibodies}

$17 \beta$-estradiol (E2), epidermal growth factor (EGF), tamoxifen and fulvestrant (ICI 182,780) were purchased from Sigma-Aldrich (St-Louis, MO, USA). G15 (GPERantagonist) was obtained from Cayman Chemical Company (Ann Arbor, MI, USA). E4 was supplied by Uteron Pharma (Liège, Belgium). All compounds were dissolved in ethanol (EtOH). Dulbecco's Modified Eagle medium (DMEM), Roswell Park Memorial Institute medium (RPMI), fetal bovine serum (FBS), dextrancoated charcoal treated-FBS, MEM-non-essential amino acid, glutamate, penicillin and streptomycin were purchased from Invitrogen (Carlsbad, CA, USA). ER $\alpha$ and GPER antibodies were purchased from Santa-Cruz Biotechnology (Santa Cruz, CA, USA). ER $\beta$ and PGR antibodies were from Novocastra (Wetslar, Germany). BCL2 antibody was from Dako (Trappes, France). Antibodies for phospho-ER $\alpha$, phospho-ERK1/2, total ERK1/2 and phospho-AKT were obtained from Cell Signaling Technology (Beverly, MA, USA).

\section{Cell culture}

Human breast cancer cells (MCF-7, T47D, MDAMB-231 and SKBR3) were purchased and authenticated from ATCC. All cell lines were authenticated within 1 year before being used in experiments. Cells were routinely cultured in DMEM supplemented with $10 \%$ FBS, L-glutamine $(2 \mathrm{mmol} / \mathrm{L})$, penicillin $(100 \mathrm{IU} / \mathrm{mL})$ and streptomycin $(100 \mu \mathrm{g} / \mathrm{mL})$ at $37^{\circ} \mathrm{C}$ in a $5 \% \mathrm{CO}_{2}$ humid atmosphere. $24 \mathrm{~h}$ before the experiments with steroids, the medium was removed and replaced with DMEM without phenol red supplemented with dextran-coated charcoaltreated FBS to exclude estrogenic effects caused by the medium or the serum.

\section{Cell growth assay and cell proliferation assay}

Cells were seeded in 96-well culture plates at a density of 5,000 cells/well and then incubated for $72 \mathrm{~h}$ with different concentrations of E4 or E2. Cell growth was 


\begin{tabular}{|c|c|c|}
\hline Name & Primer & \\
\hline$G A P D H$ & $\begin{array}{l}\text { FORWARD } \\
\text { REVERSE }\end{array}$ & $\begin{array}{l}\text { TGCTGTAGCCAAATTCGTTG } \\
\text { ACCAGGTGGTCTCCTCTGAC }\end{array}$ \\
\hline Cyclin D1 & $\begin{array}{l}\text { FORWARD } \\
\text { REVERSE }\end{array}$ & $\begin{array}{c}\text { GCTGTGCATCTACACCGACA } \\
\text { TTGAGCTTGTTCACCAGGAG }\end{array}$ \\
\hline$B R C A 1$ & $\begin{array}{l}\text { FORWARD } \\
\text { REVERSE }\end{array}$ & $\begin{array}{l}\text { TTGTTGATGTGGAGGAGCAA } \\
\text { GATTCCAGGTAAGGGGTTCC }\end{array}$ \\
\hline$B A D$ & $\begin{array}{l}\text { FORWARD } \\
\text { REVERSE }\end{array}$ & $\begin{array}{l}\text { CGAGTTTGTGGACTCCTTTAAGA } \\
\text { CACCAGGACTGGAAGACTCG }\end{array}$ \\
\hline$B C L 2$ & $\begin{array}{l}\text { FORWARD } \\
\text { REVERSE }\end{array}$ & $\begin{array}{l}\text { ACAGAGGATCATGCTGTACTTAAAAA } \\
\text { TTATTTCATGAGGCACGTTATTATTAG }\end{array}$ \\
\hline$P G R$ & $\begin{array}{l}\text { FORWARD } \\
\text { REVERSE }\end{array}$ & $\begin{array}{c}\text { AGCCCACAATACAGCTTCGAG } \\
\text { CCAGCCTGACAGCACTTTCT }\end{array}$ \\
\hline$P S 2$ & $\begin{array}{l}\text { FORWARD } \\
\text { REVERSE }\end{array}$ & $\begin{array}{l}\text { GCCCAGACAGAGACGTGTACAGT } \\
\text { CTGGAGGGACGTCGATGGTATTAG }\end{array}$ \\
\hline
\end{tabular}

measured by the Cyquant Kit from Invitrogen (Carlsbad, CA, USA) following the manufacturer's instructions, dosing the total quantity of DNA in a well. The amount of fluorescence was measured on a plate reader at a wavelength of excitation/emission 480/520 nm.

Cell proliferation was measured using thymidine incorporation. $24 \mathrm{~h}$ after the beginning of hormonal treatment, cells were incubated with $2 \mu \mathrm{Ci}$ of methyl- ${ }^{-3}[\mathrm{H}]$ thymidine for $48 \mathrm{~h}$ at $37^{\circ} \mathrm{C}$. After incubation, cells were washed and incubated in 5\% Trichloroacetic acid for 15 min at $4^{\circ} \mathrm{C}$ and lysed in $\mathrm{NAOH} 0.1 \mathrm{M}$ for 15 min at $37^{\circ} \mathrm{C}$. The total lysate was added to $25 \mu \mathrm{l}$ of scintillation liquid and radioactivity was counted with a $\beta$-counter (Beckman, LS-5000-CE).

\section{E-screen assay}

MCF-7 BOS cells are highly estrogen-responsive breast cancer cells and for this reason, considered as the most appropriate cell line for the E-Screen [43]. MCF7 BOS cells were routinely maintained in DMEM with Glutamax supplemented with 5\% FBS and 1\% MEMnon-essential amino acids. The assay was conducted as described previously [43]. Briefly, cells were seeded into 96-well plates at a density of 2,500 cells per well and allowed to attach for $24 \mathrm{~h}$. The seeding media was then replaced with the experimental medium consisting of phenol-red free DMEM supplemented with $1 \%$ sodium pyruvate, $1 \%$ MEM-NEAA and $10 \%$ CD-FBS. Each plate contained 1 row ( 8 wells) negative controls $(0,5 \% \mathrm{EtOH})$, 1 row positive controls (saturating concentration E2) and 8 increasing concentrations of the test chemical, tested in duplicate. Following $120 \mathrm{~h}$ incubation, the assay was terminated and the cells were fixed with a $10 \%$ solution of ice cold trichloroacetic acid for $25 \mathrm{~min}$. The plates were then washed with water, allowed to air dry and stained with $0.4 \%$ sulforhodamine $\mathrm{B}$ in $1 \%$ acetic acid for 10 min. Unbound dye was completely removed by rinsing with $1 \%$ acetic acid and bound SRB was solubilized with $10 \mathrm{mM}$ Tris. The optical density (O.D.) was read at $510 \mathrm{~nm}$ directly in the same plate on a microplate reader (Labsystems Multiskan, UK).

\section{Cell death assay}

MCF-7 cells were seeded in 96-well plates $(5,000$ cells/well) and left to adhere overnight. Cells were then treated with indicated compound and concentration. After $72 \mathrm{~h}$ of treatment, apoptosis level (histone-associated DNA fragments) was determined using the Cell Death Detection Elisa from Roche (Bâle, Switzerland) following the protocol provided by the manufacturer. Briefly, the cytoplasmic fractions were added to the 96-well ELISA plates pre-coated with the anti-histone monoclonal antibody and incubated for $2 \mathrm{~h}$ at room temperature. After washing, bound nucleosomes were detected by the addition of anti-DNA-peroxidase monoclonal antibody and reacted for $1 \mathrm{~h}$ at room temperature. After the addition of substrate, the optical density was read with a microplate reader at $405 \mathrm{~nm}$. Values were normalized to ADN content in each well.

\section{Cytotoxicity assay}

The cell cytotoxicity was determined after 72 $\mathrm{h}$ of treatment using the ApoTox-Glo Triplex Assay kit from Promega (Fitchburg, WI, USA) following the manufacturer's protocol. Fluorescent signal was determined using the plate reader Victor II-PerkinElmer. Values were normalized to ADN content in each well.

\section{Luciferase gene reporter assay}

The ER-LUC assay was performed as previously described [44]. Briefly, for seven days prior to experiments, T47D-KBluc cells were maintained in low estrogen conditions by the use of pre-assay media (RPMI, 
$10 \%$ charcoal-dextran stripped FCS, no antibiotics). For experiments, cells were seeded in white 96-well plates at a density of 10,000 cells/well and allowed to attach for $24 \mathrm{~h}$ before removal of media, and application of test chemicals in dosing media (phenol red-free RPMI, 5\% charcoaldextran stripped FCS, no antibiotics). The positive control was $1 \mathrm{nM} \mathrm{E2.} \mathrm{24h} \mathrm{after} \mathrm{application} \mathrm{of} \mathrm{test} \mathrm{and} \mathrm{control}$ solutions, a volume of Steady-Glo assay reagent from Promega (Fitchburg, USA) equal to the volume of culture media was added to allow the cell lysis. Plates were then loaded into a plate reader followed by measurement of luminescence (FLUOstar Optima, BMG Labtech GmbH).

\section{The recombinant yeast estrogen screen}

The assay was carried out exactly as described previously [45]. Briefly, growth media was inoculated with yeast stock and grown overnight in an orbital shaker at $28^{\circ} \mathrm{C}$. The assay medium consisted of $50 \mathrm{ml}$ of growth medium, chlorophenol red- $\beta$-D-galactopyranoside (10 $\mathrm{mg} / \mathrm{l}$ ) and $2 \mathrm{ml}$ of the overnight yeast culture. Aliquots of $10 \mu \mathrm{l}$ of the ethanolic dilutions of E2 or E4 were transferred to 96-well plates and allowed to evaporate to dryness. Final tested concentrations of E2 and E4 ranged between $1 \times 10^{-12}$ and $1 \times 10^{-8}$, and $1 \times 10^{-8}$ and $1 \times 10^{-4} \mathrm{M}$, respectively. All plates included a row of EtOH controls (i.e. no test agent) and a row of assay medium without yeast cells (blanks). To each well, except the blanks, a volume of $200 \mu \mathrm{l}$ of yeast-seeded assay medium was added. Plates were sealed and shaken vigorously for 2 min before incubating at $32{ }^{\circ} \mathrm{C}$, in a humidified box for $72 \mathrm{~h}$. Plates were then analyzed spectrophotometrically at $540 \mathrm{~nm}$ (color) and $620 \mathrm{~nm}$ (turbidity) using a Labsystem Multiskan Multisoft plate reader.

\section{Western blot analysis}

Cell were exposed to test chemicals during appropriate time, and then lysed in lysis buffer containing a protease inhibitor. $20 \mu \mathrm{g}$ of whole cell total proteins were separated onto SDS-polyacrylamide gels and transferred to nitrocellulose membrane. Membrane was blocked with 5\% milk/PBS/Tween and incubated with primary antibodies overnight at $4^{\circ} \mathrm{C}$. Membranes were then washed and incubated with appropriate HRP-conjugated secondary antibodies and detected using an ECL system. $\beta$-actin was used as a control for equal loading and total protein in case of phosphorylated protein. Results of densitometry analyses of western blots, obtained using QuantityOne software from Biorad (Hercules, CA, USA), are presented as optical densities relative to the control.

\section{Quantitative real-time PCR}

Total RNA was extracted from cells using Trizol Reagent from Invitrogen (Carlsbad, CA, USA) according to the manufacturer's protocol. The cDNA was synthesized with $2 \mu \mathrm{g}$ of total RNA using random primers for $1 \mathrm{~h}$ at $37^{\circ} \mathrm{C}$. Real-time quantitative PCR was performed using specific primers and Brilliant SYBR GREEN QPCR master mix from Qiagen (Hilden, Germany). GAPDH was amplified as an internal control. Sequence primers for target genes are reported in table 1.

\section{Immunofluorescence staining}

Cells were grown on coverslips. After treatment, cells were fixed 10 minutes at room temperature with paraformaldehyde 4\%- HEPES 250nM. Cells were permeabilized 30 minutes at room temperature with PBSTriton $1 \%$. After saturation of non-specific sites with $1 \%$ PBS-BSA, cells were then incubated 2 hours at $37^{\circ} \mathrm{C}$ with progesterone receptor primary antibody. Cells were subsequently incubated for 20 minutes at $37^{\circ} \mathrm{C}$ with the fluorescent Alexa Fluor 488 conjugated IgG secondary antibody. Then, cells were stained with DAPI and the coverslips were mounted on slides with the Prolog Gold reagent from Invitrogen (Carlsbad, CA, USA).

\section{In vivo experiments}

Immunodeficient mice were ovariectomized to prevent endogenous estrogen production. MCF-7 cells ( $2 \times 10^{6}$ cells suspended in $400 \mu 1$ Matrigel) were injected subcutaneously into each flank of mice. Mice received then a daily oral administration of vehicle (peanut oil + $5 \% \mathrm{EtOH}), \mathrm{E} 2(3 \mathrm{mg} / \mathrm{kg} /$ day $)$ or E4 (0.5 to $10 \mathrm{mg} / \mathrm{kg} /$ day $)$. Mice were sacrificed and tumor weighed after 5 weeks of treatment. For combined treatment of E2+E4, mice were implanted subcutaneously with a pellet releasing E2 (1.7 mg, Innovative Research of America). When tumors were palpable and reached an average area of $40-50 \mathrm{~mm}^{2}$, animals were divided into several groups ( 5 animals /group). E2 pellets were removed from mice of the control untreated group. Other groups received a fresh E2-releasing pellet and a daily oral treatment of vehicle (peanut oil $+5 \% \mathrm{EtOH})$ or E4 (1, 3 and $10 \mathrm{mg}$ / $\mathrm{kg}$ /day). Tumors were measured every week with digital caliper and tumor volume was calculated as $\mathrm{V}\left(\mathrm{mm}^{3}\right)=\pi$ $\mathrm{x}\left[(\text { width })^{2} \mathrm{x}\right.$ length $] / 6$. After 5 weeks of treatment, mice were sacrificed. We systematically checked that untreated ovariectomized mice had an atrophied uterus $(<10 \mathrm{mg})$ and that mice implanted with an E2-releasing pellet had a significant increase of uterine weight. All animal procedures were performed according to the Federation of European Laboratory Animal Sciences Associations within 
the accredited GIGA animal facility (University of Liège).

\section{Histological analysis}

To carry out histological analysis, tumor samples were fixed in $4 \%$ formalin for $4 \mathrm{~h}$ and stored in $70 \% \mathrm{EtOH}$ before paraffin embedding. The sections were cut at 6 $\mu \mathrm{m}$. For detection of pERK and pAKT, the slides were deparaffinized in xylene and rehydrated through graded alcohols. For antigen retrieval, sections were heated in $10 \mathrm{mM}$ citrate buffer for $10 \mathrm{~min}$. The sections were then treated with $3 \% \mathrm{H}_{2} \mathrm{O}_{2}$ for 20 min to block endogenous peroxidase activity, washed with PBS, and incubated with $10 \%$ BSA for $1 \mathrm{~h}$. After blocking, the sections were incubated with the pERK antibody and pAKT antibody at 1:100, and 1:250 dilutions respectively. The slides were then incubated with biotinylated secondary antibodies for $30 \mathrm{~min}$, followed by $30 \mathrm{~min}$ incubation with streptavidinperoxidase conjugate. Antigen- antibody complex was visualized by incubation with 3,30-diaminobenzidine 5. The slides were counterstained with hematoxylin, dehydrated, and mounted using a mounting medium from Labonord (Templemars, France). Positively stained cells appeared brown.

\section{Preparation of mixtures and calculation of mixture effect predictions using dose addition model}

Dose addition (DA) is a widely used pharmacological concept for the prediction of chemical mixture effects when only the effect of individual components is known. This hypothesis expresses the expected combination effect based on the assumption that all mixture components exert their effects without influencing each other's action. Using the DA additivity prediction, it is then possible to assess experimentally observed mixture effects in terms of synergisms or antagonisms [38]. Here, the mixture experiment was designed according to the fixed mixture ratio design, where serial dilutions of a stock solution of a mixture of E4 and E2 were made and then tested.

The mathematical and statistical procedures used for calculating DA mixture effects are described in [46]. Differences between predicted and observed effects were deemed statistically significant when the prediction did not overlap with the $95 \%$ confidence belts of the experimentally observed mixture effects.

\section{Statistical analysis}

All quantitative experimental data are expressed as mean \pm SEM. Statistical analysis were conducted with GraphPad Prism 4.0 software (La Jolla, CA, USA) using one-way ANOVA followed by Student-Newman-Keuls's test or using Kruskal-Wallis followed by Dunn's test, with regard to heterosedasticity. The value of $P \leq 0.05$ was considered as statistically significant.

\section{ACKNOWLEDGMENTS}

The authors thank Erika Konradowski and Marie Dehuy for their technical assistance.

\section{FUNDING}

This work was supported by grants from the Fonds de la Recherche Scientifique - FNRS (F.R.S.-FNRS, Belgium) : FRSM 3.4557.12, FRSM 3.4567.11, Télévie 7.4524.11, Télévie 7.4604.13; the Fonds spéciaux de la Recherche (University of Liège) : FSRC- 12/64, FSRC12/92, FSRC-14/89, FSRC-14/65, FSRC-14/109, FSRC$14 / 62$; the Centre Anticancéreux près 1' Université de Liège, the Fonds Léon Fredericq (University of Liège), the Direction Générale Opérationnelle de l'Economie, de l'Emploi et de la Recherche from the Service Public de Wallonie (DGO6, SPW, Belgium) ; the Interuniversity Attraction Poles Programme - Belgian Science Policy (Brussels, Belgium) : IAP Phase VII - P7/03 ; the Plan National Cancer (Service Public Fédéral) and the Actions de Recherche Concertées (University of Liege, Belgium): A.R.C. 11/16-02.

\section{CONFLICTS OF INTEREST}

JMF is Professor at the University of Liege and Scientific Consultant for Uteron Pharma. M. Mestdagt is Scientific Consultant for Uteron Pharma.

\section{REFERENCES}

1. Rymer J, Wilson R and Ballard K. Making decisions about hormone replacement therapy. Bmj. 2003; 326:322-326.

2. Conard J and Gompel A. [Pregnancy, contraception and HRT and venous thromboembolism]. La Revue du praticien. 2007; 57:759-766.

3. Rossouw JE, Anderson GL, Prentice RL, LaCroix AZ, Kooperberg C, Stefanick ML, Jackson RD, Beresford SA, Howard BV, Johnson KC, Kotchen JM and Ockene J. Risks and benefits of estrogen plus progestin in healthy postmenopausal women: principal results From the Women's Health Initiative randomized controlled trial. JAMA. 2002; 288:321-333.

4. Scarabin PY. Hormone therapy and venous thromboembolism among postmenopausal women. Frontiers of hormone research. 2014; 43:21-32.

5. Beral V and Million Women Study C. Breast cancer and hormone-replacement therapy in the Million Women Study. Lancet. 2003; 362:419-427. 
6. Lyytinen H, Pukkala E and Ylikorkala O. Breast cancer risk in postmenopausal women using estradiol-progestogen therapy. Obstetrics and gynecology. 2009; 113:65-73.

7. Foidart JM, Desreux J, Pintiaux A and Gompel A. Hormone therapy and breast cancer risk. Climacteric. 2007; 10 Suppl 2:54-61.

8. Hagen AA, Barr $\mathrm{M}$ and Diczfalusy E. Metabolism of 17-Beta-Oestradiol-4-14-C in Early Infancy. Acta endocrinologica. 1965; 49:207-220.

9. Tskitishvili E, Nisolle M, Munaut C, Pequeux C, Gerard C, Noel A and Foidart JM. Estetrol attenuates neonatal hypoxic-ischemic brain injury. Experimental neurology. 2014; 261C:298-307.

10. Pluchino N, Santoro AN, Casarosa E, Giannini A, Genazzani A, Russo M, Russo N, Petignat P and Genazzani AR. Effect of estetrol administration on brain and serum allopregnanolone in intact and ovariectomized rats. The Journal of steroid biochemistry and molecular biology. 2014; 143:285-290.

11. Holinka CF, Brincat $M$ and Coelingh Bennink HJ. Preventive effect of oral estetrol in a menopausal hot flush model. Climacteric. 2008; 11 Suppl 1:15-21.

12. Coelingh Bennink HJ, Heegaard AM, Visser M, Holinka CF and Christiansen C. Oral bioavailability and bone-sparing effects of estetrol in an osteoporosis model. Climacteric. 2008; 11 Suppl 1:2-14.

13. Abot A, Fontaine C, Buscato M, Solinhac R, Flouriot G, Fabre A, Drougard A, Rajan S, Laine M, Milon A, Muller I, Henrion D, Adlanmerini M, Valera MC, Gompel A, Gerard C, et al. The uterine and vascular actions of estetrol delineate a distinctive profile of estrogen receptor alpha modulation, uncoupling nuclear and membrane activation. EMBO molecular medicine. 2014; 6:1328-1346.

14. Holinka CF and Gurpide E. In vivo effects of estetrol on the immature rat uterus. Biology of reproduction. 1979; 20:242246.

15. Heegaard AM, Holinka CF, Kenemans $\mathrm{P}$ and Coelingh Bennink HJ. Estrogenic uterovaginal effects of oral estetrol in the modified Allen-Doisy test. Climacteric. 2008; 11 Suppl 1:22-28.

16. Coelingh Bennink HJ, Skouby S, Bouchard P and Holinka CF. Ovulation inhibition by estetrol in an in vivo model. Contraception. 2008; 77:186-190.

17. Gerard C, Blacher S, Communal L, Courtin A, Tskitishvili E, Mestdagt M, Munaut C, Noel A, Gompel A, Pequeux C and Foidart JM. Estetrol is a weak estrogen antagonizing estradiol-dependent mammary gland proliferation. The Journal of endocrinology. 2015; 224:85-95.

18. Coelingh Bennink HJ, Singer C, Simoncini T, Genazzani A and Kubista E. Estetrol, a pregnancy-specific human steroid, prevents and supresses mammary tumor growth in a rat model. Climateric. 2008; 11 Suppl 1:29.

19. Jozan S, Kreitmann B and Bayard F. Different effects of oestradiol, oestriol, oestetrol and of oestrone on human breast cancer cells (MCF-7) in long term tissue culture. Acta endocrinologica. 1981; 98:73-80.

20. Liu S, Ruan X, Schultz S, Neubauer H, Fehm T, Seeger $\mathrm{H}$ and Mueck AO. Oestetrol stimulates proliferation and oestrogen receptor expression in breast cancer cell lines: Comparison of four oestrogens. The European journal of contraception \& reproductive health care : the official journal of the European Society of Contraception. 2014:1-7.

21. Singer CF, Bennink HJ, Natter C, Steurer S, Rudas M, Moinfar F, Appels N, Visser M and Kubista E. Antiestrogenic effects of the fetal estrogen estetrol in women with estrogen-receptor positive early breast cancer. Carcinogenesis. 2014; 35:2447-2451.

22. Giretti MS, Montt Guevara MM, Cecchi E, Mannella P, Palla G, Spina S, Bernacchi G, Di Bello S, Genazzani AR, Genazzani AD and Simoncini T. Effects of Estetrol on Migration and Invasion in T47-D Breast Cancer Cells through the Actin Cytoskeleton. Frontiers in endocrinology. 2014; 5:80.

23. Deroo BJ and Korach KS. Estrogen receptors and human disease. The Journal of clinical investigation. 2006; 116:561-570.

24. McKenna NJ and O'Malley BW. Nuclear receptors, coregulators, ligands, and selective receptor modulators: making sense of the patchwork quilt. Annals of the New York Academy of Sciences. 2001; 949:3-5.

25. Metivier R, Penot G, Hubner MR, Reid G, Brand H, Kos $\mathrm{M}$ and Gannon F. Estrogen receptor-alpha directs ordered, cyclical, and combinatorial recruitment of cofactors on a natural target promoter. Cell. 2003; 115:751-763.

26. Soltysik K and Czekaj P. Membrane estrogen receptors - is it an alternative way of estrogen action? Journal of physiology and pharmacology : an official journal of the Polish Physiological Society. 2013; 64:129-142.

27. Chambliss KL, Wu Q, Oltmann S, Konaniah ES, Umetani M, Korach KS, Thomas GD, Mineo C, Yuhanna IS, Kim SH, Madak-Erdogan Z, Maggi A, Dineen SP, Roland CL, Hui DY, Brekken RA, et al. Non-nuclear estrogen receptor alpha signaling promotes cardiovascular protection but not uterine or breast cancer growth in mice. The Journal of clinical investigation. 2010; 120:2319-2330.

28. Poulard C, Treilleux I, Lavergne E, BouchekiouaBouzaghou K, Goddard-Leon S, Chabaud S, Tredan O, Corbo L and Le Romancer M. Activation of rapid oestrogen signalling in aggressive human breast cancers. EMBO molecular medicine. 2012; 4:1200-1213.

29. Prossnitz ER and Barton M. The G-protein-coupled estrogen receptor GPER in health and disease. Nature reviews Endocrinology. 2011; 7:715-726.

30. Gompel A, Somai S, Chaouat M, Kazem A, Kloosterboer HJ, Beusman I, Forgez P, Mimoun M and Rostene W. Hormonal regulation of apoptosis in breast cells and tissues. Steroids. 2000; 65:593-598.

31. Yamnik RL and Holz MK. mTOR/S6K1 and MAPK/RSK 
signaling pathways coordinately regulate estrogen receptor alpha serine 167 phosphorylation. FEBS letters. 2010; 584:124-128.

32. Levin ER. G protein-coupled receptor 30: estrogen receptor or collaborator? Endocrinology. 2009; 150:1563-1565.

33. Jeffy BD, Hockings JK, Kemp MQ, Morgan SS, Hager JA, Beliakoff J, Whitesell LJ, Bowden GT and Romagnolo DF. An estrogen receptor-alpha/p300 complex activates the BRCA-1 promoter at an AP-1 site that binds Jun/Fos transcription factors: repressive effects of p53 on BRCA-1 transcription. Neoplasia. 2005; 7:873-882.

34. Hilton TL, Li Y, Dunphy EL and Wang EH. TAF1 histone acetyltransferase activity in Sp1 activation of the cyclin D1 promoter. Molecular and cellular biology. 2005; 25:43214332.

35. Won Jeong K, Chodankar R, Purcell DJ, Bittencourt D and Stallcup MR. Gene-specific patterns of coregulator requirements by estrogen receptor-alpha in breast cancer cells. Molecular endocrinology. 2012; 26:955-966.

36. Silva E, Kabil A and Kortenkamp A. Cross-talk between non-genomic and genomic signalling pathways - distinct effect profiles of environmental estrogens. Toxicology and applied pharmacology. 2010; 245:160-170.

37. Madak-Erdogan Z, Lupien M, Stossi F, Brown M and Katzenellenbogen BS. Genomic collaboration of estrogen receptor alpha and extracellular signal-regulated kinase 2 in regulating gene and proliferation programs. Molecular and cellular biology. 2011; 31:226-236.

38. Scholze M, Silva E and Kortenkamp A. Extending the applicability of the dose addition model to the assessment of chemical mixtures of partial agonists by using a novel toxic unit extrapolation method. PloS one. 2014; 9:e88808.

39. Coelingh Bennink F, Holinka CF, Visser M and Coelingh Bennink HJ. Maternal and fetal estetrol levels during pregnancy. Climacteric. 2008; 11 Suppl 1:69-72.

40. Revankar CM, Cimino DF, Sklar LA, Arterburn JB and Prossnitz ER. A transmembrane intracellular estrogen receptor mediates rapid cell signaling. Science. 2005; 307:1625-1630.

41. Scaling AL, Prossnitz ER and Hathaway HJ. GPER mediates estrogen-induced signaling and proliferation in human breast epithelial cells and normal and malignant breast. Hormones \& cancer. 2014; 5:146-160.

42. Pedram A, Razandi M and Levin ER. Nature of functional estrogen receptors at the plasma membrane. Molecular endocrinology. 2006; 20:1996-2009.

43. Silva E, Lopez-Espinosa MJ, Molina-Molina JM, Fernandez M, Olea N and Kortenkamp A. Lack of activity of cadmium in in vitro estrogenicity assays. Toxicology and applied pharmacology. 2006; 216:20-28.

44. Evans RM, Rahte $\mathrm{S}$ and Kortenkamp A. Inability to confirm estrogenicity of the heterocyclic amine $\mathrm{PhIP}$ in two in vitro assays. Toxicology in vitro : an international journal published in association with BIBRA. 2010; 24:1757-1763.
45. Rajapakse N, Ong D and Kortenkamp A. Defining the impact of weakly estrogenic chemicals on the action of steroidal estrogens. Toxicological sciences : an official journal of the Society of Toxicology. 2001; 60:296-304.

46. Rajapakse N, Silva E, Scholze M and Kortenkamp A. Deviation from additivity with estrogenic mixtures containing 4-nonylphenol and 4-tert-octylphenol detected in the E-SCREEN assay. Environmental science \& technology. 2004; 38:6343-6352. 